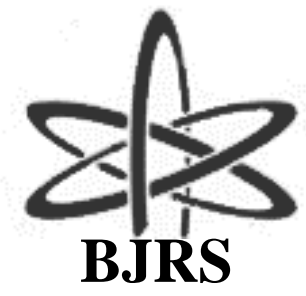

\author{
BRAZILIAN JOURNAL \\ $\mathrm{OF}$ \\ RADIATION SCIENCES \\ 07 (2019) 01-15
}

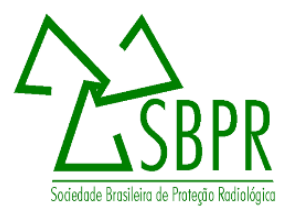

\title{
Validation study of voxel phantom monte carlo simulations with EGSnrc C++ class library
}

\author{
Paixão ${ }^{a}$ L., Mendes ${ }^{b}$ B.M., Fonseca ${ }^{c}$ T.C.F. \\ ${ }^{a}$ Departamento de Anatomia e Imagem/ Faculdade de Medicina/UFMG, 30130-100, Belo Horizonte, MG, Brasil \\ ${ }^{b}$ Centro de Desenvolvimento da Tecnologia Nuclear, 31270-901, Belo Horizonte, MG, Brasil \\ ${ }^{c}$ Departamento de Engenharia Nuclear/Escola de Engenharia/U FMG, 31270-901, Belo Horizonte, MG, Brasil \\ lucaspaixao@ufmg.br
}

\begin{abstract}
The aim of this work is to validate an in-house tool which writes voxel phantoms input files according to EGSnre C++ class library (egspp) for Monte Carlo simulations. This tool was developed to read a phantom binary file and write a voxel phantom input deck file according to egspp structures. For the validation of the new tool, three voxel phantoms from literature considering different levels of complexity were used. They are the DM_BRA mouse phantom, Golem anthropomorphic phantom, and Case 5 XCAT model phantom from AAPM TG 195 report. For the different cases of study, internal and external photon sources were set and the energy deposition for different source and target tissue/organs were calculated. The results showed good agreement when comparing to dose calculates obtained with other Monte Carlo codes and published in the literature. The new tool was then validated for the egspp Monte Carlo studies with voxel phantoms.
\end{abstract}

Keywords: EGSnrc, Monte Carlo, Voxel Phantom. 


\section{INTRODUCTION}

Generally, validation of a Monte Carlo (MC) model is performed by comparing the simulated results to experimental values as well as to previous published Monte Carlo results. Recently, the report of American Association of Physicists in Medicine (AAPM) Research Committee Task Group (TG) 195 published a set of cases for investigators to benchmark their Monte Carlo models and simulations in the field of imaging research including Computed Tomography, Mammography, and Body and Breast Tomosynthesis [1]. The six cases presented in TG 195 report were performed by various investigators using four well established Monte Carlo codes: EGSnrc [2], MCNP [3], PENELOPE [4], and GEANT4 [5]. The Monte Carlo Modeling Expert Group (MCMEG) is a work group with members from different institutes around the world and it has been working with a similar goal [6]. Intercomparison exercises are launched to model and simulate different cases of studies and each research group is free to choose among the different MC codes available. The main goal is to compare the final results obtained from the different institutes, analyzing the influence of the choices made by each group members and discuss them. The MCMEG first intercomparison was a radiotherapy case. Seven institutes joined in the modeling and simulate a $6 \mathrm{MV}$ Linac x-ray beam and validated the results by comparing to the experimental measurements of dosimetric quantities [6]. In 2017, the second exercise was launched and a prostate radiotherapy treatment planning was proposed. In this case, a voxelized pelvis phantom is asked to be modeled. This type of anthropomorphic computational voxel phantoms are often used in MC simulations [7-13]. They include details about the shape, volume, mass, density and chemical composition of human body radiosensitive organs or tissues. Thus, they are suitable to simulate the radiation interaction with matter and the absorbed dose distribution through MC codes. The EGSnrc MC code is a general purpose radiation transport package widely used and validated for medical physics research. The C++ class library (egspp) [14] provides tools for source and complex geometries modeling. Currently, to our knowledge, there is no generally available tool to build voxel models according to egspp from voxel phantom files. Therefore, an in-house computational tool was developed to accomplish this task. The aim of this work is to generate different voxel phantom input files using the developed tool and validate the MC simulations with egspp. 


\section{MATERIALS AND METHODS}

An in-house tool was developed to read the voxel phantom binary file and write an input file according to egspp. The voxel phantom geometry is constructed using the egs_ndgeometry library with EGS_XYZGeometry type. Furthermore, both source organs and detector organs can be generated. When the source organs option is selected, the egs_isotropic_source library will be written with the selected regions as isotropic voxel sources. If the detector organs option is selected, an ausgab object with the egs_dose_scoring library will be written with the dose regions as voxel detectors. In the case of a large number of voxel detectors, this option is not suitable because of a large amount of data that would be generated as result of the simulation. In this case, the egs_dose_scoring library with the medium dose option instead of the region dose option is preferable. For the validation of the new tool, the EGSnrc code 2017 version and tutor7pp usercode was used to execute the input files $[2,14]$. The MC simulations were performed on a computer with eight Intel ${ }^{\circledR}$ Core ${ }^{\mathrm{TM}}$ i 7 of $3.40 \mathrm{GHz}$ and $8 \mathrm{~GB}$ RAM. Internal and external photon sources were considered and three voxel phantoms with different levels of complexity were taking into account: DM_BRA mouse phantom [15], Golem anthropomorphic phantom [16], and case 5 XCAT model phantom from AAPM TG 195 report [1]. The results were validated using the relative percentage difference $(\triangle \%)$ as follows:

$$
\Delta \%=100 \%\left(q-q_{0}\right)\left(q_{0}\right)^{-1}
$$

where $q$ are the results calculated in this work and $q_{0}$ are the results taken as reference.

\subsection{DM_BRA mouse phantom}

The DM_BRA voxel phantom (Figure 1) was created from "Digimouse" project images [17, 18]. Digimouse is 3D Mouse Atlas. It was created using coregistered cryosections, $\mathrm{x}-\mathrm{ray} \mathrm{CT}$ and PET images. Many structures were segmented from these data such as brain, heart, lungs, liver, stomach, spleen, pancreas, kidneys, bladder, skeleton and skin. The binary image (8 bits unassigned) of the DM_BRA is 152 x 396 x 42 and the voxels dimensions are $0.25 \mathrm{~mm}$ x $0.25 \mathrm{~mm}$ 
x $0.50 \mathrm{~mm}$ representing a $28 \mathrm{~g}$ male nude mouse [15]. 23 organs/tissues were segmented and their chemical compositions and densities were based on human data, present in ICRP Publication 110 [18]. The bone tissues were defined from values given in ICRU Report 44 [19]. The heart was considered the source organ. Monoenergetic photons of $0.015,0.1,0.5$, and $4 \mathrm{MeV}$ were simulated uniformly distributed in each heart voxel. Energy deposition in target tissue/organs - skeleton, heart, bladder, stomach, spleen, pancreas, liver, kidneys, adrenals, and lungs - were computed and Specific Absorbed Fraction (SAF) values were calculated. The SAF of a given radiation energy is the ratio between the fraction of the radiation emitted by the source region that is absorbed in the target region and the mass of the target region, in $\mathrm{kg}^{-1}$. For the validation, SAF values calculated by Mendes et al. [15] using MCNPx Monte Carlo code were considered as reference values. Since the masses of tissues/organs are necessary for SAF calculations, they were also compared.

Figure 1: 3D view of DM_BRA mouse phantom (not all organs/tissues represented).

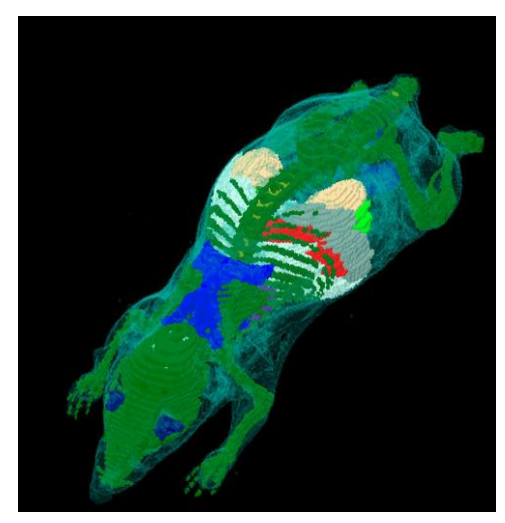

The MC transport parameters used for deposited energy calculations were $1 \mathrm{keV}$ photon and electron cutoff energy, XCOM photon and Compton cross sections and NIST bremsstrahlung cross sections. Rayleigh scattering and the impulse approximation incoherent scattering function (SIMPLE bound Compton scattering) were also considered. Furthermore, no variance reduction techniques were used. The number of simulated particles was $5 \times 10^{6}$ which provides uncertainty less than $5 \%$ in the calculated SAF values. 


\subsection{Golem anthropomorphic phantom}

The Golem phantom binary data was kindly provided by the German Research Center for Environmental Health (GSF). The phantom binary image ( 8 bits unassigned) (Figure 2) is 256 x 256 x 220 and the voxel dimensions are $2.08 \mathrm{~mm}$ x $2.08 \mathrm{~mm}$ x $8.0 \mathrm{~mm}$ representing an adult male of $172 \mathrm{~cm}$ high and with a weight of $68.9 \mathrm{~kg}$ [16]. The Golem phantom has one hundred twenty-two organs or tissues segmented with nine different materials: hard bone, skin, muscle tissue, soft tissue, red bone marrow (RBM), yellow bone marrow (YBM), adipose tissue, lung, and air. The atomic composition and density of each material were based on ICRU Report 44 [20]. Its bones were defined by different combinations of hard bone (medium 1), RBM (medium 5) and YBM (medium 6): 1, 1/6, and 1/5/6. In this work, organs/tissues assigned with bone combinations $1 / 6$ and 1/5/6 were modeled with atomic compositions of hand bones, spongiosa $\left(\rho=1.108 \mathrm{~g} / \mathrm{cm}^{3}\right)$ and ribs, spongiosa $\left(\rho=1.165 \mathrm{~g} / \mathrm{cm}^{3}\right)$ from ICRP Publication 110 [19], respectively.

Figure 2: Coronal and sagittal views of Golem phantom.

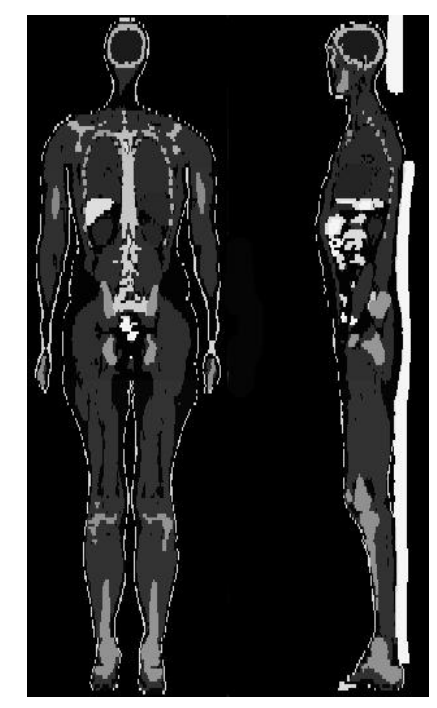

Petoussi-Henß and Zankl [16] was considered the reference used in this task. The following organs were defined as both source and target organs: spleen, brain, liver, adrenals, pancreas, lungs, kidneys and thyroid. Monoenergetic photons of $30 \mathrm{keV}, 100 \mathrm{keV}$, and $1 \mathrm{MeV}$ were simulated 
uniformly distributed in each source organ. The specific absorbed fraction values for photons were calculated and compared to the reference values as well as the MCNP5 calculated values obtained from Mendes et al. [21]. The same MC parameters used in DM_BRA energy deposition calculations were used. The masses of source organs were also compared with reference values from Petoussi-Henss and Zankl [16].

\subsection{AAPM TG 195 report: Case 5 phantom}

The Case 5 of AAPM TG 195 report describes a Computed Tomography (CT) set up with a voxelized phantom. The report provides a three-dimensional (3D) image of a torso region of a human patient (Figure 3). The 3D matrix is 320 x 500 x 260 voxels of $1 \mathrm{~mm}$ x $1 \mathrm{~mm}$ x $1 \mathrm{~mm}$.

Figure 3: Coronal and sagittal views of human torso phantom.

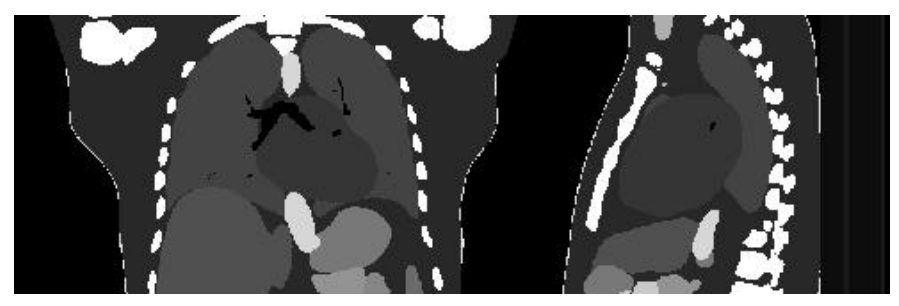

The phantom is segmented using twenty different materials being seventeen tissue/organs: soft tissue, heart, lung, liver, gallbladder, spleen, stomach, large intestine, pancreas, adrenal, thyroid, thymus, small intestine, esophagus, skin, breast, and cortical bone. The elemental composition and density of each material are also provided and are from various sources [1]. Since the AAPM TG 195 report describes accurately the geometry, materials, source properties, and scoring, they are briefly described here. The MC simulations are performed for monoenergetic photons of $56.4 \mathrm{keV}$ and for W/Al $120 \mathrm{kVp} \mathrm{x}$-ray spectrum. Only the discrete source was considered in this work. The source rotates $360^{\circ}$ around the isocenter in $45^{\circ}$ increments $\left(0^{\circ}\right.$ min and $315^{\circ}$ max $)$. The rotation radius of the $\mathrm{x}$-ray source about the isocenter, located at the center of the body phantom, is $600 \mathrm{~mm}$. The source photons are collimated to a fan beam at the voxel phantom center with $500 \mathrm{~mm}$ width 
and $10 \mathrm{~mm}$ thickness. Energy deposited in each organ per incident photon is computed and compared to TG 195 report values. The same MC parameters used in the previous simulations were used except that electron transport was not considered [1] and $5 \times 10^{8}$ particles were simulated.

\section{RESULTS AND DISCUSSION}

\subsection{SAF values for DM_BRA and Golem phantom}

The energy deposited in various target organs was computed in the MC simulations. Based on these results Specific Absorbed Fraction (SAF) values were calculated for DM_BRA and Golem voxel phantoms. The uncertainties of SAF values $(1 \sigma)$ calculated in this work were propagated from MC uncertainties by using the law of propagation of uncertainty [22]. Table 1 shows the SAF values calculated using DM_BRA mouse voxel phantom for ten target tissue/organs. The heart was considered the source and five different monoenergetic photons were simulated. The results from Mendes et al. [15] using MCNPx are also shown and are taken as reference values.

Table 1: Specific Absorbed Fractions for DM_BRA mouse voxel phantom.

\begin{tabular}{ccccccccccccc}
\hline $\begin{array}{c}\text { Energy } \\
(\mathbf{M e V})\end{array}$ & Study & \multicolumn{8}{c}{ Photon Specific Absorbed Fraction - SAF (kg ${ }^{-1}$ ) - Source Organ = Heart } \\
\cline { 2 - 12 } & Skeleton & Heart & Bladder & Stomach & Spleen & Pancreas & Liver & Kidneys & Adrenals & Lungs \\
\hline \multirow{2}{*}{0.015} & MCNPx & 46 & 1300 & 0.24 & 11 & 3.1 & 2.9 & 35 & 1.5 & 4.5 & 310 \\
& EGSnrc & 46.78 & 1347 & 0.19 & 11.15 & 3.22 & 2.9 & 35.15 & 1.56 & 4.6 & 315.7 \\
& $\Delta \%$ & $2 \%$ & $4 \%$ & $-21 \%$ & $1 \%$ & $4 \%$ & $1 \%$ & $0 \%$ & $4 \%$ & $2 \%$ & $2 \%$ \\
\multirow{4}{*}{0.1} & MCNPx & 1.3 & 31 & 0.23 & 1.3 & 0.64 & 0.63 & 2 & 0.48 & 0.64 & 8.5 \\
& EGSnrc & 1.31 & 31.7 & 0.23 & 1.27 & 0.69 & 0.64 & 1.98 & 0.47 & 0.66 & 8.65 \\
& $\Delta \%$ & $1 \%$ & $2 \%$ & $-2 \%$ & $-2 \%$ & $8 \%$ & $1 \%$ & $-1 \%$ & $-1 \%$ & $4 \%$ & $2 \%$ \\
0.5 & MCNPx & 1.1 & 36 & 0.29 & 1.5 & 0.81 & 0.72 & 2.4 & 0.6 & 0.98 & 11 \\
& EGSnrc & 1.152 & 36.8 & 0.29 & 1.52 & 0.82 & 0.82 & 2.4 & 0.59 & 1.1 & 10.64 \\
& $\Delta \%$ & $5 \%$ & $2 \%$ & $0 \%$ & $1 \%$ & $2 \%$ & $14 \%$ & $0 \%$ & $-1 \%$ & $16 \%$ & $-3 \%$ \\
1 & MCNPx & 1 & 26 & 0.28 & 1.4 & 0.79 & 0.73 & 2.2 & 0.58 & 0.83 & 9.2 \\
& EGSnrc & 1.074 & 27 & 0.271 & 1.4 & 0.82 & 0.77 & 2.257 & 0.56 & 0.85 & 9.20 \\
& $\Delta \%$ & $7 \%$ & $4 \%$ & $-3 \%$ & $0 \%$ & $3 \%$ & $5 \%$ & $3 \%$ & $-3 \%$ & $3 \%$ & $0 \%$ \\
& MCNPx & 0.43 & 4.1 & 0.19 & 0.82 & 0.51 & 0.49 & 0.98 & 0.38 & 0.68 & 1.9 \\
4 & EGSnrc & 0.447 & 4.31 & 0.184 & 0.854 & 0.521 & 0.483 & 1.014 & 0.401 & 0.64 & 1.921 \\
& $\Delta \%$ & $4 \%$ & $5 \%$ & $-3 \%$ & $4 \%$ & $2 \%$ & $-1 \%$ & $4 \%$ & $6 \%$ & $-5 \%$ & $1 \%$ \\
\hline
\end{tabular}


The adrenals were the only tissue that presented different organ mass in comparison with Mendes et al. [15]. However, the $2 \%$ mass difference was not considered important. The uncertainty of SAF values was kept less than 5\% for most organs. Only the bladder (7\% uncertainty for $15 \mathrm{keV}$ ) and adrenals $(9 \%, 11 \%, 9 \%$, and $7 \%$ for $15 \mathrm{keV}, 100 \mathrm{keV}, 0.5 \mathrm{MeV}$, and $1 \mathrm{MeV}$, respectively) SAF uncertainties were greater than 5\%. The small size of adrenals helps to explain the larger uncertainties. Also, both adrenals and bladder are distant from the source organ. The mean relative percentage difference $(\Delta \%)$ from MCNPx SAF results was $(2 \pm 5) \%$ with values equal or less than $5 \%$ for most cases/organs. The minimum and maximum differences were $0 \%$ for liver and $-21 \%$ for bladder, respectively. Mohammadi and Kinase [23] also study the same case, but they used a slightly different phantom [15]. They found a SAF value of $0.19 \mathrm{~kg}^{-1}$ for Heart source $\rightarrow$ Bladder $_{\text {target}}$, for $15 \mathrm{keV}$ photons. This is the same value obtained in this work. The Heart $_{\text {source }} \rightarrow$ Adrenal $_{\text {target }} \mathrm{SAF}$ value for $0.5 \mathrm{MeV}$ photons also shows a large $\Delta \%$ from reference work (16\%). In this case, Mohammadi and Kinase [23] and Mendes et al. [15] show a better agreement $\left(0.97 \mathrm{~kg}^{-1}\right.$ and $\left.0.98 \mathrm{~kg}^{-1}\right)$ compared to ours $\left(1.1 \mathrm{~kg}^{-1}\right)$. Even so, considering the relatively large relative errors $(\sim 9 \%)$ from simulation, the differences among the values are not statistically significant.

Table 2 shows the SAF values calculated using Golem anthropomorphic voxel phantom for eight source/target tissue/organs and three monoenergetic photons. The specific absorbed fraction values calculated were compared to the reference values from Petoussi-Henß and Zankl [16] and MCNP5 calculated values from Mendes et al. [21].

Table 2: Specific Absorbed Fractions for Golem anthropomorphic voxel phantom.

\begin{tabular}{lcccccccccc}
\hline source & \multicolumn{3}{c}{ 30 keV } & \multicolumn{4}{c}{ 100 keV } & \multicolumn{3}{c}{ 1 MeV } \\
\cline { 2 - 11 } target & Golem & MCNP5 & EGSnrc & Golem & MCNP5 & EGSnrc & Golem & MCNP5 & EGSnrc \\
\hline Adrenals & 5.3 & 5.7 & 5.316 & 0.94 & 1 & 0.935 & 1 & 1.1 & 0.895 \\
Brain & 0.46 & 0.45 & 0.4645 & 0.13 & 0.13 & 0.1293 & 0.12 & 0.12 & 0.1158 \\
Kidneys & 1.1 & 1.1 & 1.114 & 0.24 & 0.24 & 0.2396 & 0.23 & 0.23 & 0.2205 \\
Liver & 0.36 & 0.36 & 0.3636 & 0.11 & 0.11 & 0.1097 & 0.094 & 0.094 & 0.0926 \\
Lungs & 0.29 & 0.28 & 0.2861 & 0.062 & 0.061 & 0.0614 & 0.055 & 0.055 & 0.0518 \\
Pancreas & 3.5 & 3.6 & 3.54 & 0.69 & 0.7 & 0.6888 & 0.69 & 0.7 & 0.6516 \\
Spleen & 2 & 2 & 2.028 & 0.43 & 0.43 & 0.4266 & 0.42 & 0.42 & 0.4016 \\
Thyroid & 6.3 & 6.5 & 6.328 & 1.1 & 1.2 & 1.115 & 1.2 & 1.2 & 1.102 \\
\hline
\end{tabular}


Again the adrenals were the only tissue that presented different organ mass. In comparison with reference values, the difference was $1 \%$ and also was not considered important. The number of histories chosen in this work $\left(5 \times 10^{6}\right)$ was exaggerated and the uncertainty of all calculated SAF values was equal or less than $0.2 \%$. The mean relative percentage difference from Petoussi-Hen $\beta$ and Zankl [16] SAF results was $(2 \pm 3) \%$. For $30 \mathrm{keV}$ and $100 \mathrm{keV}$ results, relative percentage difference ranged between $-1 \%$ and $1 \%$. The $\Delta \%$ for $1 \mathrm{MeV}$ results ranged between $2 \%$ (liver) and $11 \%$ (adrenals). The overestimation from $1 \mathrm{MeV}$ results can be explained by the fact that electron transport was considered in this work and Petoussi-Henß and Zankl considered the KERMA approximation in their Monte Carlo simulations [16]. Thus, the reference values do not take into account that secondary electrons created inside a target organ can carry their energy away from the point they were released. Hence, the overestimation for $1 \mathrm{MeV}$ SAF values. The mean $\Delta \%$ from MCNP5 SAF results was $(3 \pm 5) \%$. The maximum difference was $19 \%$ for adrenals $(1 \mathrm{MeV})$. The SAF values obtained for $30 \mathrm{keV}$ and $100 \mathrm{keV}$ photons show better agreement with reference values than MCNP5 values. Mendes et al. [21] used the MCNP tally F6:P to evaluate the energy deposited per unit of mass $(\mathrm{MeV} / \mathrm{g})$ in the organs. The energy from secondary electrons is locally deposited in such tally. This is equivalent to Petoussi-Henß and Zankl [16] KERMA approximation. This may explain better agreement between the $1 \mathrm{MeV}$ photon sources SAF values from Mendes et al. [21] and Petoussi-Henß and Zankl [16].

\subsection{Energy deposited per initial photons for case 5 phantom of AAPM TG 195 report}

The energy deposited per initial photon in seventeen target organs were computed for case 5 voxelized phantom of AAPM TG 195 report. Tables 3 and 4 show relative percentage differences between the results obtained with EGSnrs and the mean results of the report [1] for monoenergetic source and W/Al $120 \mathrm{kVp}$ x-ray spectrum source, respectively. The uncertainty obtained for all calculated energy deposited per initial photon values was equal or less than $3 \%$, except for the adrenals which the uncertainties were equal or less than $8 \%$. The mean $\Delta \%$ from AAPM TG 195 report results was $(4 \pm 2) \%$ and $(3 \pm 2) \%$ for monoenergetic and spectrum source, respectively. 
Table 3: $\Delta \%$ for case 5 monoenergetic source mean results.

\begin{tabular}{ccccccccc}
\hline & \multicolumn{7}{|c}{$\left.\boldsymbol{\theta} \mathbf{(}^{\mathbf{0}}\right)$} \\
\cline { 2 - 8 } Voxel material & $\mathbf{0}$ & $\mathbf{4 5}$ & $\mathbf{9 0}$ & $\mathbf{1 3 5}$ & $\mathbf{1 8 0}$ & $\mathbf{2 2 5}$ & $\mathbf{2 7 0}$ & $\mathbf{3 1 5}$ \\
\hline Soft tissue & $3 \%$ & $3 \%$ & $4 \%$ & $3 \%$ & $3 \%$ & $3 \%$ & $4 \%$ & $3 \%$ \\
Heart & $3 \%$ & $3 \%$ & $3 \%$ & $3 \%$ & $3 \%$ & $3 \%$ & $3 \%$ & $3 \%$ \\
Lung & $3 \%$ & $3 \%$ & $3 \%$ & $3 \%$ & $3 \%$ & $3 \%$ & $3 \%$ & $3 \%$ \\
Liver & $4 \%$ & $4 \%$ & $4 \%$ & $3 \%$ & $3 \%$ & $3 \%$ & $3 \%$ & $3 \%$ \\
Gallbladder & $5 \%$ & $5 \%$ & $4 \%$ & $5 \%$ & $2 \%$ & $3 \%$ & $3 \%$ & $5 \%$ \\
Spleen & $3 \%$ & $3 \%$ & $5 \%$ & $3 \%$ & $3 \%$ & $4 \%$ & $5 \%$ & $4 \%$ \\
Stomach & $4 \%$ & $3 \%$ & $4 \%$ & $2 \%$ & $4 \%$ & $4 \%$ & $3 \%$ & $4 \%$ \\
Large Intestine & $4 \%$ & $3 \%$ & $7 \%$ & $4 \%$ & $3 \%$ & $4 \%$ & $3 \%$ & $4 \%$ \\
Pancreas & $3 \%$ & $4 \%$ & $1 \%$ & $2 \%$ & $4 \%$ & $4 \%$ & $3 \%$ & $5 \%$ \\
Adrenal & $10 \%$ & $-5 \%$ & $5 \%$ & $15 \%$ & $1 \%$ & $3 \%$ & $7 \%$ & $0 \%$ \\
Thyroid & $4 \%$ & $5 \%$ & $6 \%$ & $1 \%$ & $4 \%$ & $3 \%$ & $8 \%$ & $3 \%$ \\
Thymus & $2 \%$ & $2 \%$ & $3 \%$ & $2 \%$ & $2 \%$ & $2 \%$ & $4 \%$ & $3 \%$ \\
Small Intestine & $5 \%$ & $5 \%$ & $3 \%$ & $3 \%$ & $4 \%$ & $3 \%$ & $2 \%$ & $3 \%$ \\
Esophagus & $3 \%$ & $3 \%$ & $4 \%$ & $4 \%$ & $3 \%$ & $4 \%$ & $3 \%$ & $3 \%$ \\
Skin & $3 \%$ & $3 \%$ & $3 \%$ & $3 \%$ & $3 \%$ & $3 \%$ & $4 \%$ & $3 \%$ \\
Breast & $5 \%$ & $5 \%$ & $5 \%$ & $2 \%$ & $1 \%$ & $4 \%$ & $4 \%$ & $5 \%$ \\
Cortical Bone & $3 \%$ & $3 \%$ & $3 \%$ & $3 \%$ & $3 \%$ & $3 \%$ & $3 \%$ & $3 \%$ \\
\hline
\end{tabular}

Table 4: $\Delta \%$ for case 5 spectrum source mean results.

\begin{tabular}{lcccccccc}
\hline & \multicolumn{7}{c}{$\boldsymbol{\theta} \mathbf{(}^{\mathbf{9}} \mathbf{c}$} \\
\cline { 2 - 8 } Voxel Material & $\mathbf{0}$ & $\mathbf{4 5}$ & $\mathbf{9 0}$ & $\mathbf{1 3 5}$ & $\mathbf{1 8 0}$ & $\mathbf{2 2 5}$ & $\mathbf{2 7 0}$ & $\mathbf{3 1 5}$ \\
\hline Soft tissue & $3 \%$ & $3 \%$ & $3 \%$ & $3 \%$ & $3 \%$ & $3 \%$ & $3 \%$ & $3 \%$ \\
Heart & $3 \%$ & $3 \%$ & $3 \%$ & $3 \%$ & $3 \%$ & $3 \%$ & $4 \%$ & $3 \%$ \\
Lung & $3 \%$ & $3 \%$ & $3 \%$ & $3 \%$ & $3 \%$ & $3 \%$ & $3 \%$ & $3 \%$ \\
Liver & $4 \%$ & $4 \%$ & $4 \%$ & $4 \%$ & $4 \%$ & $3 \%$ & $4 \%$ & $3 \%$ \\
Gallbladder & $6 \%$ & $6 \%$ & $2 \%$ & $6 \%$ & $4 \%$ & $7 \%$ & $1 \%$ & $5 \%$ \\
Spleen & $3 \%$ & $5 \%$ & $3 \%$ & $5 \%$ & $4 \%$ & $4 \%$ & $5 \%$ & $5 \%$ \\
Stomach & $4 \%$ & $3 \%$ & $5 \%$ & $3 \%$ & $4 \%$ & $4 \%$ & $4 \%$ & $3 \%$ \\
Large Intestine & $4 \%$ & $4 \%$ & $4 \%$ & $6 \%$ & $4 \%$ & $4 \%$ & $5 \%$ & $4 \%$ \\
Pancreas & $3 \%$ & $2 \%$ & $5 \%$ & $4 \%$ & $5 \%$ & $4 \%$ & $3 \%$ & $4 \%$ \\
Adrenal & $4 \%$ & $7 \%$ & $11 \%$ & $2 \%$ & $-5 \%$ & $-3 \%$ & $-8 \%$ & $6 \%$ \\
Thyroid & $1 \%$ & $3 \%$ & $6 \%$ & $7 \%$ & $4 \%$ & $3 \%$ & $6 \%$ & $7 \%$ \\
Thymus & $3 \%$ & $2 \%$ & $3 \%$ & $3 \%$ & $4 \%$ & $1 \%$ & $2 \%$ & $2 \%$ \\
Small Intestine & $5 \%$ & $2 \%$ & $3 \%$ & $1 \%$ & $3 \%$ & $4 \%$ & $5 \%$ & $5 \%$ \\
Esophagus & $3 \%$ & $3 \%$ & $4 \%$ & $2 \%$ & $4 \%$ & $3 \%$ & $3 \%$ & $3 \%$ \\
Skin & $3 \%$ & $3 \%$ & $3 \%$ & $3 \%$ & $3 \%$ & $3 \%$ & $3 \%$ & $3 \%$ \\
Breast & $6 \%$ & $5 \%$ & $7 \%$ & $4 \%$ & $-1 \%$ & $3 \%$ & $5 \%$ & $5 \%$ \\
Cortical Bone & $3 \%$ & $3 \%$ & $3 \%$ & $3 \%$ & $3 \%$ & $3 \%$ & $3 \%$ & $3 \%$ \\
\hline
\end{tabular}


The $\Delta \%$ for all results ranged between $0 \%$ and $15 \%$. Only the adrenals presented $\Delta \%$ larger than $10 \%$ (15\% for $135^{\circ}$ projection angle of monoenergetic source and $11 \%$ for $90^{\circ}$ projection angle of spectrum source). The larger uncertainties and discrepancies for the adrenals were expected due to its small size. An estimate of organ masses was made and is presented in Table 5.

Table 5: Human torso voxel phantom organ/tissue masses.

\begin{tabular}{lc}
\hline Voxel material & mass $(\mathbf{g})$ \\
\hline Soft tissue & 10501 \\
Heart & 960 \\
Lung & 705 \\
Liver & 1445 \\
Gallbladder & 40 \\
Spleen & 119 \\
Stomach & 372 \\
Large Intestine & 76 \\
Pancreas & 54 \\
Adrenal & 2 \\
Thyroid & 12 \\
Thymus & 29 \\
Small Intestine & 65 \\
Esophagus & 63 \\
Skin & 224 \\
Breast & 27 \\
Cortical Bone & 2596 \\
\hline
\end{tabular}

\section{CONCLUSION}

The aim of this work was to validate a new tool developed for automatically write a voxel phantom input file according to EGSnrc C++ class library (egspp) for Monte Carlo simulations. This in-house tool reads the phantom binary file and writes the voxel phantom structure according to egspp. Three different voxel phantoms were used for the validation process. Internal and external photon sources were set and the energy deposition for different source and target tissue/organs were calculated. The results showed good agreement compared with values published in the literature. Some results presented differences up to $21 \%$ but mean relative percentage differences of less than 
$5 \%$ for each case studied were found. Thus, these results validate the tool developed to generate voxel phantom input files for Monte Carlo studies.

\section{ACKNOWLEDGMENT}

The authors are thankful to Pró-Reitoria de Pesquisa from Universidade Federal de Minas Gerais (PRPq-UFMG) for fomentation through the edital number 05/06 and to Laboratório de Ciências Radiológicas from Universidade do Estado do Rio de Janeiro for the use of their computer cluster in performing some of the simulation tests.

\section{REFERENCES}

[1] SECHOPOULOS, I.; ALI, E. S. M.; BADAL, A.; BADANO, A.; BOONE, J. M.; KYPRIANOU, I. S.; MAINEGRA-HING, E.; MCMILLAN, K. L.; MCNITT-GRAY, M. F.; ROGERS, D. W. O.; SAMEI, E.; TURNER, A. C. Monte Carlo reference data sets for imaging research: executive summary of the report of AAPM research committee task group 195. Med Phys, v. 42, p. 5679-5691, 2015.

[2] KAWRAKOW, I.; MAINEGRA-HING, E.; ROGERS, D. W. O.; TESSIER, F.; WALTERS, B. R. B. The EGSnrc code system: monte carlo simulation of electron and photon transport. NRCC Report PIRS-701, Ottawa: National Research Council of Canada, Ottawa, 2011. 317p.

[3] PELOWITZ, D. B.; HENDRICKS, J. S.; DURKEE, J. W.; JAMES, M. R.; FENSIN, M. L.; MCKINNEY, G. W.; MASHNIK, S. G.; WATERS, L. S. MCNPX 2.7.A Extensions. Report LA-UR-08-07182, Los Alamos: LANL, 2008.

[4] SALVAT, F.; FERNÁNDEZ-VAREA, J. M.; SEMPAU, J. PENELOPE-2011: a code system for monte carlo simulation of electron and photon transport. NEA/NSC/DOC(2011)5, Issyles-Moulineaux: OECD-NEA, 2011. 385p.

[5] AGOSTINElli, S.; AlliSON, J.; AMAKO, K.; APOSTOLAKIS, J.; ARAUJO, H.; ARCE, P.; ASAI, M.; AXEN, D.; BANERJEE, S.; BARRAND, G.; BEHNER, F.; BELLAGAMBA, 
L.; BOUDREAU, J.; BROGLIA, L.; BRUNENGO, A.; BURKHARDT, H.; CHAUVIE, S.; CHUMA, J.; CHYTRACEK, R.; COOPERMAN, G.; COSMO, G.; DEGTYARENKO, P.; DELl'ACQUA, A.; DEPAOLA, G.; DIETRICH, D.; ENAMI, R.; FELICIELlO, A.; FERGUSON, C.; FESEFELDT, H.; FOLGER, G.; FOPPIANO, F.; FORTI, A.; GARELLI, S.; GIANI, S.; GIANNITRAPANI, R.; GIBIN, D.; CADENAS, J. J. G.; GONZALEZ, I.; ABRIL, G. G.; GREENIAUS, G.; GREINER, W.; GRICHINE, V.; GROSSHEIM, A.; GUATELLI, S.; GUMPLINGER, P.; HAMATSU, R.; HASHIMOTO, K.; HASUI, H.; HEIKKINEN, A.; HOWARD, A.; IVANCHENKO, V.; JOHNSON, A.; JONES, F. W.; KALLENBACH, J.; KANAYA, N.; KAWABATA, M.; KAWABATA, Y.; KAWAGUTI, M.; KELNER, S.; KENT, P.; KIMURA, A.; KODAMA, T.; KOKOUliN, R.; KOSSOV, M.; KURASHIGE, H.; LAMANNA, E.; LAMPEN, T.; LARA, V.; LEFEBURE, V.; LEI, F.; LIENDL, M.; LOCKMAN, W. ; LONGO, F.; MAGNI, S.; MAIRE, M.; MEDERNACH, E.; MINAMIMOTO, K.; FREITAS, P. M.; MORITA, Y.; MURAKAMI, K.; NAGAMATU, M.; NARTALLO, R.; NIEMINEN, P.; NISHIMURA, T.; OHTSUBO, K.; OKAMURA, M.; O’NEALE, S.; OOHATA, Y.; PAECH, K.; PERL, J.; PFEIFFER, A.; PIA, M. G.; RANJARD, F.; RYBIN, A.; SADILOV, S.; DI SALVO, E.; SANTIN, G.; SASAKI, T.; SAVVAS, N.; SAWADA, Y.; SCHERER, S.; SEI, S.; SIROTENKO, V.; SMITH, D.; STARKOV, N.; STOECKER, H.; SULKIMO, J.; TAKAHATA, M.; TANAKA, S.; TCHERNIAEV, E.; TEHRANI, E. S.; TROPEANO, M.; TRUSCOTT, P.; UNO, H.; URBAN, L.; URBAN, P.; VERDERI, M.; WALKDEN, A.; WANDER, W.; WEBER, H.; WELLISCH, J. P.; WENAUS, T.; WILliAMS, D. C.; WRIGHT, D.; YAMADA, T.; YOSHIDA, H.; ZSCHIESCHE, D. GEANT4-a simulation toolkit. Nucl Instrum Methods Phys Res, Sect A, v. 506, p. 250-303, 2003.

[6] FONSECA, T. C. F.; MENDES, B. M.; LACERDA, M. A. S.; SILVA, L. A. C.; PAIXÃO, L.; BASTOS, F. M.; RAMIREZ, J.V.; JUNIOR, J. P. R. MCMEG: simulations of both PDD and TPR for 6 MV LINAC photon beam using different MC codes. Radiat Phys Chem, v. 140, p. 386-391, 2017.

[7] FONSECA, T. C. F.; BOGAERTS, R.; LEBACQ, A.L.; RIBEIRO, R. M.; VANHAVERE, F. MaMP and FeMP: computational mesh phantoms applied for studying the variation of WBC efficiency using a NaI(Tl) detector. J Radiol Prot, v. 34, p. 529-543, 2014. 
[8] FONSECA, T. C. F.; BOGAERTS, R.; HUNT, J.; VANHAVERE, F. A methodology to develop computational phantoms with adjustable posture for WBC calibration. Phys Med Biol, v. 59, p. 6811-6825, 2014.

[9] XU, X. G. An exponential growth of computational phantom research in radiation protection, imaging, and radiotherapy: a review of the fifty-year history. Phys Med Biol, v. 59, p. R233R302, 2014.

[10] PAIXÃO, L.; OLIVEIRA, B. B.; OLIVEIRA, M. A.; TEIXEIRA, M. H. A.; FONSECA, T. C. F.; NOGUEIRA, M. S. New method for generating breast models featuring glandular tissue spatial distribution. Radiat Phys Chem, v. 119, p. 200-206, 2016.

[11] MENDES, B. M.; TRINDADE, B. M.; FONSECA, T. C. F.; CAMPOS, T. P. R. Assesment of radiation-induced secondary cancer risk in the brazilian population from left-sided breast-3DCRT using MCNPX. Brit J Radiol, v. 90, p. 20170187, 2017.

[12] HAN, M. C.; SEO, J. M.; LEE, S. H.; KIM, C. H.; YEOM, Y. S.; NGUYEN, T. T.; CHOI, C.; KIM, S.; JEONG, J. H.; SOHN, J. W. Continuously deforming 4D voxel phantom for realistic representation of respiratory motion in monte carlo dose calculation. IEEE Trans Nucl Sci, v. 63, p. 2918-2924, 2016.

[13] VILlOING, D.; MARCATILI, S.; GARCIA, M. P.; BARDIÈS, M. Internal dosimetry with the Monte Carlo code GATE: validation using the ICRP/ICRU female reference computational model. Phys. Med. Biol., v. 62, p. 1885-1904, 2017.

[14] KAWRAKOW, I.; MAINEGRA-HING, E.; TESSIER, F.; WALTERS, B. R. B. The EGSnrc C++ class library. NRC Report PIRS-898 (rev A), Ottawa: National Research Council of Canada, 2009.

[15] MENDES, B. M.; ALMEIDA, I. G.; TRINDADE, B. M.; FONSECA, T. C. F.; CAMPOS, T. P. R. Development of a mouse computational model for MCNPx based on Digimouse ${ }^{\circledR}$ images and dosimetric assays. Braz J Pharm Sci, v. 53, p. 1-12, 2017.

[16] PETOUSSI-HENß, N.; ZANKL, M. Voxel anthropomorphic models as a tool for internal dosimetry. Radiat Prot Dosim, v. 79, p. 415-418, 1998.

[17] STOUT, D.; CHOW, P.; SILVERMAN, R.; LEAHY, R. M.; LEWIS, X.; GAMBHIR, S.; CHATZIIOANNOU, A. Creating a whole body digital mouse atlas with PET, CT and cryosection images. Mol Imaging Biol, v. 4, p. S27, 2002. 
[18] DOGDAS, B.; STOUT, D.; CHATZIIOANNOU, A. F.; LEAHY, R. M. Digimouse: a 3D whole body mouse atlas from CT and cryosection data. Phys. Med. Biol., v. 52, p. 577-587, 2007.

[19] ICRP Publication 110. Realistic reference phantoms: an ICRP/ICRU joint effort. A report of adult reference computational phantoms. Ann ICRP, v. 39, p. 1-164, 2009.

[20] ICRU - International Commission on Radiation Units and Measurements. Tissue substitutes in radiation dosimetry and measurement. ICRU Report 44, Bethesda: ICRU, 1989.

[21] MENDES, B. M.; TRINDADE, B. M.; FONSECA, T. C. F.; CAMPOS, T. P. R. Validation of internal dosimetry protocols based in stochastic method. In: Proc. International Nuclear Atlantic Conference, 2015, São Paulo. Annals... São Paulo: Comissão Nacional de Energia Nuclear, 2015. p. 01-10.

[22] TAYLOR, B. N.; KUYATT, C. E. Guidelines for evaluating and expressing the uncertainty of NIST measurements results. NIST Technical Note 1297, Washington: NIST, 1994.

[23] MOHAMMADI, A.; KINASE, S. Monte Carlo simulations of photon specific absorbed fractions in a mouse voxel phantom. Prog Nucl Sci Technol, v. 1, p. 126-129, 2011. 